\title{
The Wrexham Titan prison and the case against prison expansion
}

\author{
Emily Luise Hart, \\ Liverpool Hope University, UK
}

Raphael Schlembach, University of Brighton, UK

\section{Pre-Print Version}

This is the author's pre-print (before peer review) version of the article published in Critical and Radical Social Work 3 (2), 289-294, August 2015. For the published version please see: http://www.ingentaconnect.com/content/tpp/crsw/2015/00000003/00000002/art00009

\begin{abstract}
The building of a new 'super prison' in Wrexham, North Wales has begun amidst a wider expansion of the penal industrial complex. Campaigns are mobilising nationally and locally against the project. This article examines the concerns surrounding what will become the United Kingdom's largest prison and argues that its construction is a symptom of a wider ideological attack on marginalised groups while also examining the case against prison expansion.
\end{abstract}

Keywords prison abolition • austerity • prison industrial complex

\section{Introduction}

The current number of prisoners in England and Wales stands at 85,590 as of 8 May 2015 (www.gov.uk). This figure excludes those in a secure children's home, those detained under the Mental Health Act and individuals held in Britain's Immigration Removal Centres. This figure continues to rise and has almost doubled over the last 20 years placing England and Wales's carceral inflation at the top of the table for its per capita prison population in Western Europe. Recent projections by the Ministry of Justice (MoJ) suggest that the prison population will rise by approximately 5,000 in the next five years (MoJ, 2014).

This expansion of prisons and increase in prison population has been implemented under successive Labour and Conservative-led governments and stands to increase further with a prison building programme set to forge ahead following the recent election result. This accompanies the continuing neoliberal policy agenda that has already cut deep into the country's social fabric. Ideological attacks on welfare, in tandem with increased penal security is far from a new development. However, there are currently concrete moves to further expand the penal-industrial complex in the form of a prison building programme that will see the introduction of US style 'titan prisons' in the UK.

Just prior to the General Election the MoJ signed the contract to begin the construction of the country's first 'super prison' in Wrexham, North Wales (www.wrexham.gov.uk). This will be a custodial facility holding more than 2,000 category $C$, male prisoners and will now be managed by the prison service (MoJ, 2015). This will be one of the largest prisons in Europe, the biggest in the UK by quite some margin and is part of a wider prison building 
programme that includes plans for a 300 bed titan children's prison in Leicester. The UK's current biggest prison is HMP Oakwood near Wolverhampton which opened in 2012 with a capacity of 1,600 . It is a privately run prison managed by scandal-hit G4S. HMP Oakwood is far from a success, having been subject to increasingly poor inspection reports with high levels of violence and self-harm (HM Chief Inspector of Prisons, 2013).

\section{A Prison Crisis?}

The new Conservative administration has made it clear that the country is to face continued and increased levels of austerity and cuts to public services. With this in mind, one of the driving forces behind the building of larger facilities is an attempt to minimise running costs. Following five years of the Coalition's austerity agenda, the prison system in England and Wales faces chronic conditions of overcrowding and severe shortages of prison staff. Figures by the MoJ show that the number of assaults in English and Welsh prisons have risen in the last year by approximately one thousand (MoJ, 2014a). Worryingly, these figures also highlight significant increases in the number of self-inflicted deaths in custody, from 52 to 88 in a year's period. In addition the National Offender Management Service reported that one quarter of jails were 'of concern' or in the 'of serious concern' category (NOMS 2014). These figures are a direct result of falling prison officer numbers which have been cut by 30 per cent over three years with some establishments having the number of officer's halved (Howard League for Penal Reform, 2014).

Government ministers, notably the previous government's Justice Secretary Chris Grayling, have denied that the prison system is in crisis (Guardian, 2014). Frances Crook, chief executive of the Howard League however claims that the prison system is not only in crisis, but in a state of emergency (ref- website?!). The prevalence in use of the term "crisis" in both political and academic debates follows a series of critical inspection reports overseen by the chief inspector of prisons Nick Hardwick. Hardwick has directly linked increasing levels of violence and self-harm in prisons to continued policy failures. In addition he has called for the government to conduct and publish a review into the difficulties faced by new prisons, including HMP Oakwood before any 'titan' prisons are opened (HM Chief Inspector of Prisons, 2015).

There is certainly clear evidence of strains within the prison system as a result of recent cuts. This is not in doubt. However, the terms 'crisis' and 'emergency' are misleading. They imply that current concerns over conditions and the continued injustices faced by prisoners are new developments, that the prison system has reached a critical point, and that it is on the brink of collapse. In reality, the situation is far worse. Prisons in the UK have been dangerous and overcrowded institutions for decades. They house increasingly disproportionate numbers of vulnerable and marginalised groups; a fact which successive governments have not only refused to address but have exacerbated through the continued implementation of punitive policy agendas.

\section{Punitiveness as an ideological force}

The prison population is far from representative. Prisoners are disproportionately from ethnic minority backgrounds. Scott and Codd argue that "the disproportionate confinement of black or minority ethnic people and foreign national offenders is clear evidence of 
accumulative racism in the criminal justice system" (2010: 167). If we consider that the majority of prisoners also suffer from multiple mental health concerns, are predominantly working class and have lower than average educational attainment it can be argued that prisons are little more than the bureaucratic containment of marginal populations.

The government's prison building program highlighted above is part of a wider ideological commitment to continually expand the penal-industrial complex and further service the interests of government and industry through increased control, surveillance, and containment of minority groups. Instead of working towards the rehabilitation of offenders, the government's prison programme is trying to rehabilitate the role of the prison itself amidst a more punitive workfare regime. The prison industrial complex, of course, comprises not just prisons themselves but a mutually reinforcing web of relationships, between prisons, the probation service, police and the courts plus an increasing number of companies that profit from the transportation and feeding of prisoners as well as the running of private prisons, immigration removal centres and the construction of establishments like that in Wrexham.

Just as with the cuts to public sector provisions, there can be little doubt that the punitive rampage of the Coalition government was deeply ideological and it is hard to see how this will alter with a Michael Gove led Ministry. The new Conservative government's neoliberal austerity policies will see those stigmatised as the feral underclass trapped between the complementary poles of workfare and the criminal justice system.

\section{Re-imagining Prison Abolition}

There have been numerous penal reforms throughout history which have undoubtedly improved the lives of many prisoners and their families. It is also important to note that there are some individuals that work within these institutions who are committed to improving the day to day existence of those incarcerated populations (Sim 2009). However, a continued reformist agenda without questioning the legitimacy of prisons themselves can conversely lead to the strengthening of the legitimacy of penal sanctions. If the role of the prison is to prevent or reduce crime then the reformed prison has not worked (Fitzgerald and Sim, 1979). If however the role of the prison is to socially control and marginalise the more vulnerable members of our communities then this has clearly been a far more successful endeavour (Foucault, 1977). Cohen (1998) argues for the development of policies that reduce harms to those currently experiencing incarceration but at the same time keeping in mind the goal of abolition. The issue of whether punishment can ever be legitimate needs to be addressed as currently those in power claim a moral validity to incarceration which in turn has led to widespread consent. In reality incarceration is dehumanizing and too often an infringement of human rights. The situation for women prisoners is of particular concern. Women in prison almost all have one or more mental health conditions (Ministry of Justice, 2013) and have numerous issues surrounding motherhood (Caddle and Crisp, 1997), including separation from their children and the problems associated with regaining custody of them after release. They are more likely than men to be victims of domestic violence and sexual abuse (Corston, 2007; Ministry of Justice, 2012) and suffer greater levels of economic marginalisation. The treatment of women in 
custody has been described as forms of institutional sexual, emotional and physical abuse (Scott and Codd, 2010).

The prison abolition movement in the US has long been part of a wider struggle in terms of civil rights. This locating of abolitionist arguments within a broader fight for social justice has not mobilised in the same way in the UK with reformist pressure groups granted the greater voice. This, as stated, can lead to the long term maintenance of dehumanising incarceration with continued injustice hidden behind a veneer of reform. "As important as some reforms might be...frameworks that rely exclusively on reforms help to produce the stultifying idea that nothing lies beyond the prison" (Davis, 2003: 20).

Abolition is not simply halting the construction and dismantling of penal institutions in a vacuum. It is about building a movement for wider social and political change and struggling for a justice system built on social justice, harm reduction and human and civil rights. This form of 'abolition democracy' argues that the social, economic and political systems on which the penal industrial complex is built will also need to be dismantled (Davis, 2005).

\section{Conclusions}

Increasing prison populations or the building of titan prisons in Wrexham or anywhere else serve no purpose in protecting the public, fail to reform or rehabilitate offenders and play no role in supporting victims of crime. The presumed logic is clear: more prisoners are a result of increasing crime rates. But with flattening crime figures, this argument simply does not hold. Just as the attacks on the benefits system, the use of incarceration is ideologically motivated.

The real success of prisons is their entrenchment in the capitalist economy, in people's consciousness and the belief that they are inevitable and indispensable. However, governments, policy makers, practitioners, activists and scholars also need to re-engage with the abolitionist debate and construct a narrative of immediate harm reduction while campaigning for a future landscape without prisons; a future where there are real alternatives to addressing issues of harm, where being a victim of poverty and social exclusion does not lead to involvement in the criminal justice system.

In the UK a campaign against the Wrexham prison has been mobilising across the North West with meetings taking place across the region and locally to discuss the concerns. Groups are also mobilising nationally with a new campaign network launched in the UK. Community Action on Prison Expansion (CAPE) has an abolitionist agenda at its core and is utilising a diverse range of tactics to counter attempts to expand the prison industrial complex. Plans are also afoot for a large prison abolition conference later this year bringing activists, campaigners and scholars together in order to formulate strategy and to mobilise further action. 


\section{References}

Caddle, D. and Crisp, D. (1997) Imprisoned women and mothers Home Office Research Study 162. London: Home Office

Corston, J. (2007) The Corston Report: A Report by Baroness Jean Corston of a Review of Women with Particular Vulnerabilities in the Criminal Justice System. London: Home Office

Davis, A. (2003) Are Prisons Obsolete? New York: Open Media

Davis, A. (2005) Abolition Democracy, London: Seven Stories Press

Fitzgerald, M. and Sim, J. (1979) British Prisons, Oxford: Blackwell

Foucault, M. (1977) Discipline and Punish, Harmondsworth: Penguin

Guardian, 2014 [online] http://www.theguardian.com/society/2014/aug/19/graylingdenies-prison-crisis-inmate-numbers

HM Chief Inspector of Prisons, 2013. Report on an unannounced inspection of HMP Oakwood. London: HMIP

HM Chief Inspector of Prisons, 2015. Report on an announced inspection of HMP Oakwood. London: HMIP

Howard League for Penal Reform, 2014. Breaking point: Understaffing and overcrowding in prisons Research briefing. London: Howard League for Penal Reform

Ministry of Justice (2012) Prisoners' childhood and family backgrounds. London: Ministry of Justice

Ministry of Justice (2013) Gender differences in substance misuse and mental health amongst prisoners. London: Ministry of Justice

Ministry of Justice (2015) New prison to be run by Her Majesty's Prison Service (HMPS), Press Release [online] https://www.gov.uk/government/news/new-prison-to-be-run-byher-majestys-prison-service-hmps

Ministry of Justice (2014) Prison Population Projections 2014-2020 England and Wales, Ministry of Justice Statistics Bulletin, London: Ministry of Justice

Ministry of Justice (2014a) Safety in Custody Statistics England and Wales Update to March 2014 Ministry of Justice Statistics Bulletin, London: Ministry of Justice

NOMS (2014) National Offender Management Service Prison Annual Performance Ratings 2013/14 
Scott, D. and Codd, H. (2010) Controversial Issues in Prison, Maidenhead: Open University Press

Sim, J. (2009) Prisons and Punishment, London: Sage

http://www.wrexham.gov.uk/english/business/prison/

https://www.gov.uk/government/statistics/prison-population-figures-2015 